\title{
Nuclear magnetic resonance and potentiometric studies of the complexation of methylmercury(II) by dithiols
}

\author{
Alan P. Arnold and Allan J. Canty' \\ Department of Chemistry, University of Tasmania, Hobart, Tasmania, Australia 7001 \\ AND \\ R. Stephen Reid and Dallas L. Rabenstein ${ }^{1}$ \\ Department of Chemistry, University of Alberta, Edmonton, Alta., Canada T6G $2 G 2$
}

Received November 2, 1984

\begin{abstract}
Alan P. Arnold, Allan J. Canty, R. Stephen Reid, and Dallas L. Rabenstein. Can. J. Chem. 63, 2430 (1985).
Complexation of methylmercury, $\mathrm{CH}_{3} \mathrm{Hg}(\mathrm{II})$, by 2,3-dimercaptosuccinic acid (DMSA), 2,3-dimercaptopropanesulfonate (DMPS, Unithiol), dithioerythritol (DTE), and 2,3-dimercaptopropanol (British AntiLewisite, BAL) has been studied by 'H nuclear magnetic resonance spectroscopy and by potentiometric titration. In the nmr study, the equilibrium constants for displacement of mercaptoacetate from its $\mathrm{CH}_{3} \mathrm{Hg}$ (II) complex by the dithiols were determined over a wide $\mathrm{pH}$ range, from mercaptoacetate chemical shift data. Similar competition reactions between the dithiols and mercaptoethanol were used in the potentiometric study. Using previously determined $\mathrm{CH}_{3} \mathrm{Hg}(\mathrm{II})$ formation constants for the competing ligands, equilibrium constants for the formation of mono- and bis- $\mathrm{CH}_{3} \mathrm{Hg}$ (II) complexes with the dithiols have been determined. The formation constants for the mono- $\mathrm{CH}_{3} \mathrm{Hg}$ (II) complexes with the vicinal dithiols BAL and DMPS are significantly higher than expected by consideration of the basicity of the sulfhydryl donors, in comparison with those for DMSA, non-vicinal DTE, and monothiols. We interpret this to indicate chelation of $\mathrm{CH}_{3} \mathrm{Hg}$ (II) by BAL and DMPS but not by DMSA. The conditional formation constants at physiological $\mathrm{pH}$ are discussed with reference to the effectiveness of BAL, DMPS, and DMSA as antidotes for methylmercury poisoning. In particular, the constants obtained indicate that, for dithiol antidotes at concentrations greater than that of methylmercury(II), methylmercury(II) complexes formed at physiological pH are of $1: 1$ stoichiometry. For BAL, a substantial proportion of the complex will be in the neutral form, in contrast to DMPS and DMSA which form anionic species only.
\end{abstract}

Alan P. Arnold, Allan J. Canty, R. Stephen Reid et Dallas L. Rabenstein. Can. J. Chem. 63, 2430 (1985).

Faisant appel à la rmn du ' $\mathrm{H}$ et à des titrages potentiométriques, on a étudié la complexation du méthylmercure, $\mathrm{CH}_{3} \mathrm{Hg}(\mathrm{II})$, par les composés suivantes: l'acide dimercaptosuccinique (ADMS), le dimercapto-2,3 propanesulfonate (DMPS, Unithiol), le dithioérythritol (DTE) et le dimercapto-2,3 propanol (British Antilewisite, BAL). A partir des données de déplacement chimique du mercaptoacetate en $\mathrm{rmn} \mathrm{du}{ }^{\prime} \mathrm{H}$, on a déterminé, sur un large intervalle de $\mathrm{pH}$, les constantes d'équilibre des réactions de déplacement, par les dithiols, du mercaptoacétate de son complexe de $\mathrm{CH}_{3} \mathrm{Hg}$ (II). On a également utilisé des réactions de compétitions du même type entre des dithiols et le mercaptoéthanol, lors de l'étude potentiométrique. Faisant appel à des constantes de formation du $\mathrm{CH}_{3} \mathrm{Hg}$ (II) qui ont été déterminées antérieurement pour les ligands entrant en compétition, on a déterminé les constantes d'équilibre de formation des complexes mono- et bis- $\mathrm{CH}_{3} \mathrm{Hg}$ avec les dithiols. Si on les compare avec les constantes de l'ADMS, du DTE (qui sont des dithiols qui ne sont pas vicinaux) ou avec celles des monothiols, les constantes de formation des complexes de mono- $\mathrm{CH}_{3} \mathrm{Hg}(\mathrm{II})$ avec les dithiols vicinaux BAL et DMPS sont nettement plus élevées que celles prévues en tenant compte de la basicité des sulfhydryles donneurs. Pour interpréter ces résultats, nous suggérons la présence d'une chélation du $\mathrm{CH}_{3} \mathrm{Hg}$ (II) par le BAL et le DMPS qui n'existerait pas dans le cas de l'ADMS. On discute des constantes de formation conditionnelles, à $\mathrm{pH}$ physiologique, en fonction d'une utilisation possible du BAL, de l'ADMS et du DMPS comme antidotes dans les empoisonnements par le méthylmercure. En particulier, les constantes obtenues indiquent que, pour des antidotes du type dithiols agissant à des concentrations supérieures à celles de méthylmercure(II), les complexes de méthylmercure formés à des $\mathrm{pH}$ physiologiques sont du type $1: 1$. Dans le cas du BAL, une proportion importante du complexe existe sous la forme neutre, contrairement au DMPS et à l'ADMS qui forment uniquement des espèces anioniques.

[Traduit par le journal]

\section{Introduction}

Methylmercury, $\mathrm{CH}_{3} \mathrm{Hg}(\mathrm{II})$, forms very stable complexes with monothiols $(1,2)$, with the result that $\mathrm{CH}_{3} \mathrm{Hg}(\mathrm{II})$ is thought to be essentially all thiol-bound in biological systems. For example, in human erythrocytes, $\mathrm{CH}_{3} \mathrm{Hg}(\mathrm{II})$ is bound almost entirely to glutathione (ca. 51\%) and hemoglobin (ca. $49 \%)(3,4)$. Complexation therapy, using monothiols such as D-penicillamine (5) or $N$-acetyl-D, L-penicillamine (5), is one of several techniques used for treatment of $\mathrm{CH}_{3} \mathrm{Hg}$ (II) poisoning; however dithiols, such as 2,3-dimercaptosuccinic acid (DMSA) (6) and 2,3-dimercaptopropanesulfonate (DMPS, Unithiol) (7) are more effective antidotes. The non-sulfonated analog of DMPS, 2,3-dimercaptopropanol (British Anti-Lewisite, BAL),

'To whom correspondence should be addressed. is contraindicated as an antidote for $\mathrm{CH}_{3} \mathrm{Hg}$ (II) poisoning because it causes rapid redistribution of the metal into the brain (8).

Although the term "chelation therapy" is often used for such treatment, there has been no evidence that $\mathrm{CH}_{3} \mathrm{Hg}$ (II) binds simultaneously to adjacent sulfhydryl sites of these vicinal dithiols, although similar binding is found in the solid state in the $2: 1 \mathrm{CH}_{3} \mathrm{Hg}$ (II) complex of sterically rigid toluene-3,4dithiol (9).

We have measured the equilibrium constants for the binding of $\mathrm{CH}_{3} \mathrm{Hg}(\mathrm{II})$ by the vicinal dithiols BAL, DMPS, and DMSA and by non-vicinal dithioerythritol (DTE) by ${ }^{\mathrm{H}} \mathrm{H} \mathrm{nmr}$ and potentiometric titration methods. The results provide evidence that BAL and DMPS do indeed chelate $\mathrm{CH}_{3} \mathrm{Hg}$ (II) in solution, whereas DMSA and DTE do not. 
TABLE 1. Acid dissociation constants of dithiols and methylmercury(II)-dithiol complexes

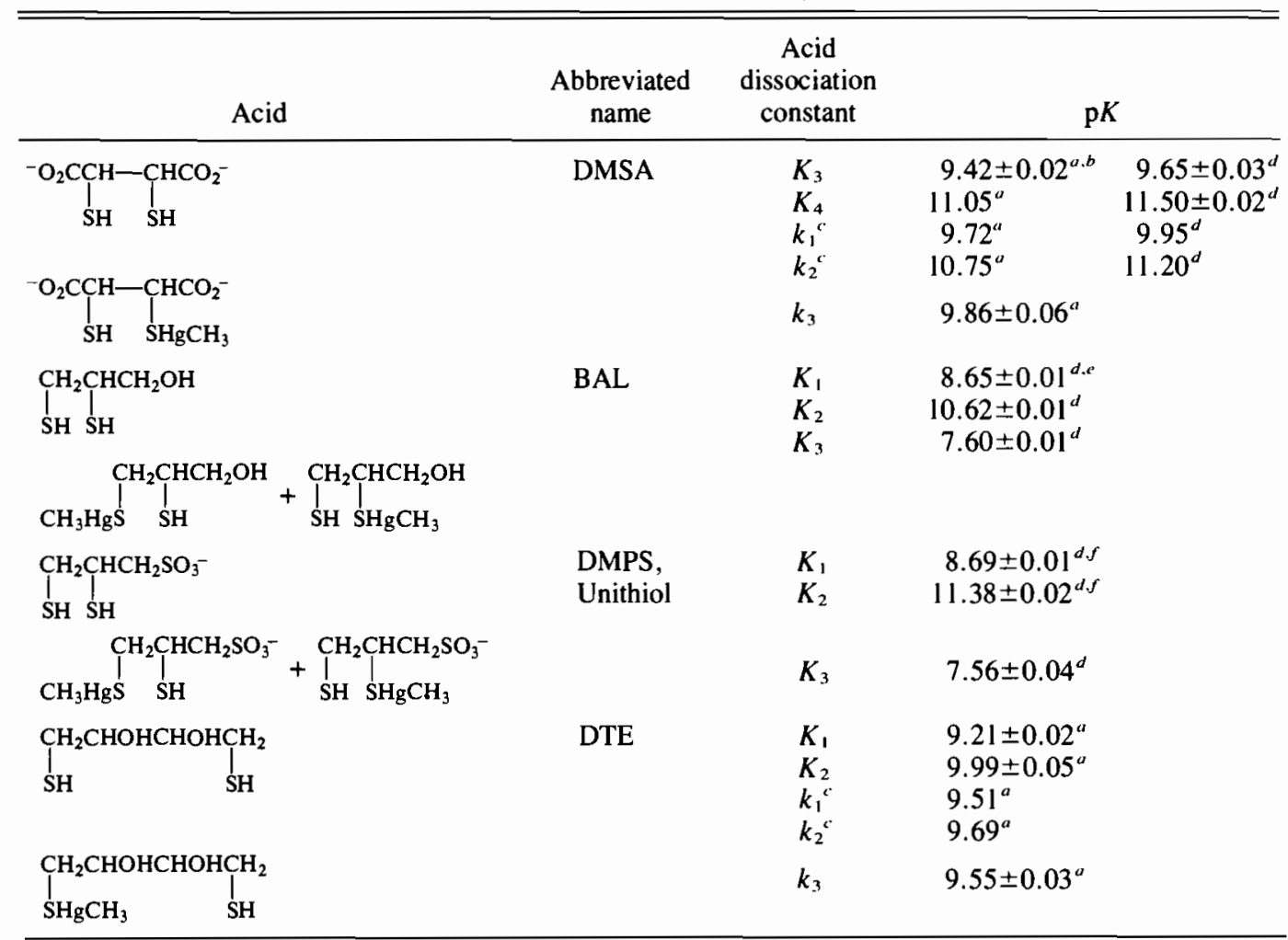

${ }^{a} 0.3 \mathrm{M} \mathrm{KNO} ; ; 25^{\circ} \mathrm{C}$. Uncertainties are the standard error of the estimate obtained from KINET fits.

${ }^{b}$ Literature values: $\mathrm{p} K_{3}=8.89, \mathrm{p} K_{4}=10.79,25^{\circ} \mathrm{C}, 0.1 M \mathrm{KNO}_{3}(23) ; \mathrm{pK} K_{3}=9.68, \mathrm{p} K_{4}=11.14,20^{\circ} \mathrm{C}, 0.1 M \mathrm{KCl}$ (24); $\mathrm{p} K_{3}=9.44, \mathrm{p} K_{4}=11.82,20^{\circ} \mathrm{C}, 0.1 \mathrm{M} \mathrm{KCl} \mathrm{(25).}$

'Microscopic constant as defined in Fig. 5.

${ }^{d} 0.1 \mathrm{M} \mathrm{KNO}{ }_{3} ; 25^{\circ} \mathrm{C}$. Uncertainties are one standard deviation obtained from MINIQUAD fits.

'Literature values: $\mathrm{p} K_{1}=8.69, \mathrm{p} K_{2}=10.79,25^{\circ} \mathrm{C}, 0.1 \mathrm{M} \mathrm{NaCl}(26) ; \mathrm{p} K_{1}=8.616, \mathrm{p} K_{2}=10.567,25^{\circ} \mathrm{C}$ (27).

${ }^{f}$ Literature values: $\mathrm{p} K_{1}=8.84, \mathrm{p} K_{2}=11.20(28) ; \mathrm{p} K_{1}=8.65(2), \mathrm{p} K_{2}=11.91(4), 25^{\circ} \mathrm{C}, 0.1 M \mathrm{KCl}(29)$.

\section{Experimental}

\section{Chemicals}

Methylmercuric iodide (Alfa Products, Morton Thiokol Inc.) was converted to stock solutions of methylmercuric hydroxide for use in ' $\mathrm{H}$ nmr (1) and potentiometric titration (2) experiments. The stock solutions were standardized as described previously. Mercaptoacetic acid, 2,3-dimercaptopropanol (Aldrich), and 2-mercaptoethanol (KochLight) were fractionally distilled under reduced nitrogen pressure. Meso-2,3-dimercaptosuccinic acid (Sigma Chemical Co.), 2,3-dimercaptopropanesulfonic acid, sodium salt (Aldrich and Heyl and Co., Chem.-Pharm. Fabrik, Berlin), and dithioerythritol (Aldrich) were used as received. All thiols were stored under inert atmosphere below $-4^{\circ} \mathrm{C}$.

\section{pH measurements}

For the ' $\mathrm{H} \mathrm{nmr}$ study, all $\mathrm{pH}$ measurements were made at $25 \pm 1{ }^{\circ} \mathrm{C}$ with an Orion Model 701 meter equipped with either a standard glass electrode - porous ceramic junction reference electrode pair, or a microcombination electrode, in solutions containing $0.3 M \mathrm{KNO}_{3}$ (1). For the equilibrium potentiometric titrations, $\mathrm{pH}$ measurements were made at $25 \pm 0.02^{\circ} \mathrm{C}$ with an Orion Model $701 \mathrm{~A}$ meter equipped with a Philips glass electrode (GATI30) and glass sleeve double-junction calomel reference electrode $(\mathrm{R} 44 / 2-\mathrm{SD} / 1)$ in solutions containing $0.1 \mathrm{M} \mathrm{KNO}_{3}(2)$.

${ }^{\prime} \mathrm{H}$ nuclear magnetic resonance measurements

Proton nmr spectra were recorded on a Varian A60D spectrometer at a probe temperature of $25 \pm 1^{\circ} \mathrm{C}$ with a sweep rate of $0.1 \mathrm{~Hz} / \mathrm{s}$. Chemical shifts were measured relative to either the central resonance of the triplet of tetramethylammonium ion or the singlet for 1,4-dioxane. Chemical shifts are reported relative to the methyl resonance of sodium 2,2-dimethyl-2-silapentane-5-sulfonate (DSS).

\section{Results}

Acid dissociation constants for the dithiols were determined potentiometrically in the ionic strength medium appropriate for subsequent determination of $\mathrm{CH}_{3} \mathrm{Hg}$ (II) formation constants by ${ }^{1} \mathrm{H} \mathrm{nmr}$ (1) or potentiometric titration (2). Particular care was taken to preclude carbonate contamination of the titrant base, and to use values of $\mathrm{p} K_{\mathrm{w}}$ determined under our experimental conditions. Both of these parameters significantly affect $\mathrm{p} K_{\mathrm{a}}$ values which are determined from data above $\mathrm{pH} 10$. Acid dissociation constants determined for the dithiols are listed in Table 1.

\section{' $H$ nmr determination of formation constants}

Formation constants for the $\mathrm{CH}_{3} \mathrm{Hg}$ (II) complexes of DMSA and DTE were determined from the exchange-averaged chemical shift of the mercaptoacetic acid (MAA) resonance in solutions containing MAA, $\mathrm{CH}_{3} \mathrm{Hg}$ (II), and the dithiol. The procedure was similar to that used to determine formation constants for monothiol $-\mathrm{CH}_{3} \mathrm{Hg}$ (II) complexes (1). Chemical shift titration data are shown in Fig. 1 for $(A)$ a solution containing only MAA, $(B)$ a solution containing the $\mathrm{CH}_{3} \mathrm{Hg}(\mathrm{II})-$ MAA complex, and $(C)$ a solution containing equimolar concentrations of MAA, $\mathrm{CH}_{3} \mathrm{Hg}(\mathrm{II})$, and DMSA. Curve $C$ lies between curves $A$ and $B$, indicating displacement of some of the complexed MAA by DMSA and fast exchange of MAA between its free and complexed forms. The exchange-averaged chemical shift of MAA yields directly $P_{\mathrm{f}}$, the proportion of uncomplexed MAA (1), from which the formation constant $K_{\mathrm{fH}}$, defined by eq. [1], 


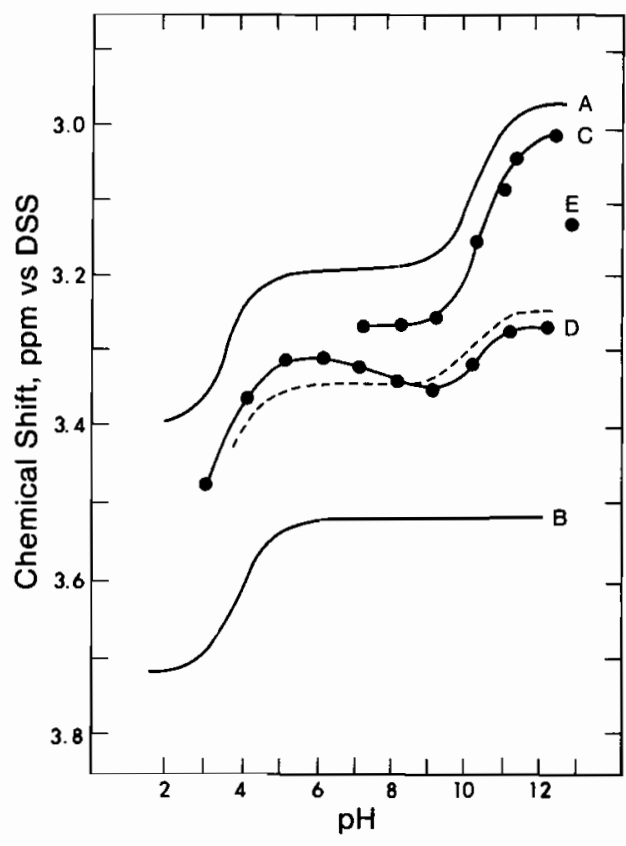

FiG. 1. $\mathrm{pH}$ dependence of the chemical shift of the exchangeaveraged MAA resonance in solutions containing $(A) 0.10 \mathrm{M} \mathrm{MAA}$, (B) $0.10 M$ MAA and $0.10 M \mathrm{CH}_{3} \mathrm{Hg}(\mathrm{II}),(C)$ as in (B) plus 1 mole equivalent of DMSA, $(D)$ as in $(B)$ plus 0.5 mole equivalent of DMPS (-•-.- experimental and --- calculated using formation constants determined by potentiometry), and (E) MAA: $\mathrm{CH}_{3} \mathrm{Hg}($ II) $:$ DTE of $2: I: 1$.

$$
\begin{array}{r}
\text { [1] } \mathrm{CH}_{3} \mathrm{Hg}^{+}+{ }^{-} \mathrm{S} \mathrm{SH} \rightleftarrows \mathrm{CH}_{3} \mathrm{HgS} \mathrm{SH} \\
\qquad k_{\mathrm{fH}}=\frac{\left[\mathrm{CH}_{3} \mathrm{HgS} \mathrm{SH}\right]}{\left[\mathrm{CH}_{3} \mathrm{Hg}^{+}\right][-\overline{\mathrm{S} \mathrm{SH}}]}
\end{array}
$$

can be calculated with eq. $[2]^{2.3}$

[2] $k_{\mathrm{fH}}^{2}\left(C_{\mathrm{M}}-\left(1-P_{\mathrm{f}}\right) C_{\mathrm{MAA}}-2 C_{\text {Dithiol }}\right) K_{\mathrm{dp}} k_{3}[\mathrm{M}]^{2} /[\mathrm{H}]^{2}$

$$
+k_{\mathrm{fH}}\left(C_{\mathrm{M}}-\left(1-P_{\mathrm{f}}\right) C_{\mathrm{MAA}}-C_{\text {Dithiol }}\right)[\mathrm{M}]\left(1+k_{3} /[\mathrm{H}]\right)
$$$$
+\left(C_{\mathrm{M}}-\left(1-P_{\mathrm{f}}\right) C_{\mathrm{MAA}}\right)\left(1+[\mathrm{H}] / K_{3}+\mathrm{K}_{4} /[\mathrm{H}]\right)=0
$$

where $C_{\mathrm{M}}, C_{\mathrm{MAA}}$, and $C_{\text {Dithiol }}$ are the total concentrations of $\mathrm{CH}_{3} \mathrm{Hg}(\mathrm{II}), \mathrm{MAA}$, and dithiol, and [M] is the concentration of free $\mathrm{CH}_{3} \mathrm{Hg}^{+} .[\mathrm{M}]=\left(1-P_{\mathrm{f}}\right) /\left(P_{\mathrm{f}} \alpha_{\text {MAA }} K_{\text {MAA }}\right)$ where $K_{\text {IMAA }}$ is the formation constant of the $\mathrm{CH}_{3} \mathrm{Hg}(\mathrm{II})-\mathrm{MAA}$ complex and $\alpha$ $=K_{\text {aMAA }} /\left([\mathrm{H}]+K_{\text {aMAA }}\right) ; K_{\text {aMAA }}$ is the acid dissociation constant for the thiol group of MAA (I). The equilibrium constants $k_{3}$ and $K_{\mathrm{dp}}$ are defined by eqs. [3] and [4]. ${ }^{2}$

[3] $\mathrm{CH}_{3} \mathrm{HgSS} \mathrm{SH} \rightleftarrows \mathrm{CH}_{3} \mathrm{HgSS} \mathrm{S}^{-}+\mathrm{H}^{+}$

$$
\begin{aligned}
& \mathrm{CH}_{3} \mathrm{HgS} \mathrm{S}^{-}+\mathrm{CH}_{3} \mathrm{HgS} \mathrm{S} \mathrm{H} \rightleftarrows \mathrm{CH}_{3} \mathrm{HgS} \mathrm{S} \mathrm{SgCH}_{3} \\
& + \text { HS S } \\
& K_{\mathrm{dp}}=\frac{\left[\mathrm{CH}_{3} \mathrm{HgSS} \mathrm{SgCH}_{3}\right]\left[\mathrm{HS} \mathrm{S}{ }^{-}\right]}{\left[\mathrm{CH}_{3} \mathrm{HgS} \mathrm{S}^{-}\right]\left[\mathrm{CH}_{3} \mathrm{HgS} \mathrm{SH}\right]}
\end{aligned}
$$

${ }^{2} \mathrm{HS} \mathrm{SH},-{ }_{\mathrm{S}} \mathrm{SH}$, and $-{ }_{\mathrm{S} \mathrm{S}}^{-}$represent dithiol, singly deprotonated dithiol, and doubly deprotonated dithiol, respectively. $\mathrm{CH}_{3} \mathrm{Hg} \widehat{S} \mathrm{SH}$ and $\mathrm{CH}_{3} \mathrm{HgS} \mathrm{S}^{-}$represent the $1: 1 \mathrm{CH}_{3} \mathrm{Hg}$ (II) complexes with singly and doubly deprotonated dithiol and $\mathrm{CH}_{3} \mathrm{HgS} \mathrm{SHgCH}_{3}$ the 2:I

\begin{tabular}{|c|c|c|}
\hline Ligand & $\begin{array}{c}\text { Formation } \\
\text { constant }\end{array}$ & $\begin{array}{l}\log \\
\text { (formation } \\
\text { constant) }\end{array}$ \\
\hline $\begin{array}{c}\mathrm{O}_{2} \mathrm{CCH}-\mathrm{CHCO}_{2}^{-} \\
\mathrm{s}^{-} \quad \mathrm{s}^{-}\end{array}$ & $\begin{array}{l}K_{\mathrm{f} 1} \\
K_{12} \\
k_{\mathfrak{r 1}{ }^{b}} \\
k_{\mathrm{f} 2}{ }^{b}\end{array}$ & $\begin{array}{l}18.4 \pm 0.2^{a} \\
16.9 \pm 0.2^{a} \\
18.1 \pm 0.2 \\
17.2 \pm 0.2\end{array}$ \\
\hline $\begin{array}{c}{ }^{-} \mathrm{O}_{2} \mathrm{CCH}-\mathrm{CH}_{2} \mathrm{CO}_{2}^{-} \\
\mathrm{S}^{-} \quad{ }_{\mathrm{SH}}\end{array}$ & $k_{\mathrm{fH}}{ }^{b}$ & $17.16 \pm 0.05^{a}$ \\
\hline $\begin{array}{l}\mathrm{CH}_{2} \mathrm{CHCH}_{2} \mathrm{OH} \\
\mid ! \\
\mathrm{s}^{-} \mathrm{s}^{-}\end{array}$ & $\begin{array}{l}K_{\text {f1 }} \\
K_{\text {f2 }}\end{array}$ & $\begin{array}{l}19.56 \pm 0.09^{c} \\
10.46 \pm 0.10^{c}\end{array}$ \\
\hline $\begin{array}{ll}\mathrm{CH}_{2} \mathrm{CHCH}_{2} \mathrm{OH} \\
\mathrm{S}^{-} \mathrm{SH}_{\mathrm{SH}}^{\mathrm{CH}_{2} \mathrm{CHCH}_{2} \mathrm{OH}}+\mathrm{l}_{\mathrm{SH}}^{\mathrm{S}^{-}}\end{array}$ & $K_{\mathrm{HH}}$ & $16.54^{\circ}$ \\
\hline $\begin{array}{l}\mathrm{CH}_{2} \mathrm{CHCH}_{2} \mathrm{SO}_{3}^{-} \\
\mathrm{s}^{-} \mathrm{s}^{-}\end{array}$ & $\begin{array}{l}K_{\text {f1 }} \\
K_{12}\end{array}$ & $\begin{array}{l}21.01 \pm 0.08^{c} \\
10.26 \pm 0.008^{c}\end{array}$ \\
\hline 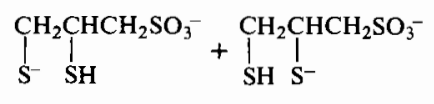 & $K_{\mathrm{rH}}$ & $17.19^{c}$ \\
\hline $\begin{array}{l}\mathrm{CH}_{2} \mathrm{CHOHCHOHCH}_{2} \\
\mathrm{~s}^{-}\end{array}$ & $\begin{array}{l}K_{\mathrm{f1}} \\
k_{\mathrm{fl}}{ }^{b}\end{array}$ & $\begin{array}{l}17.0 \pm 0.2^{\circ} \\
16.7 \pm 0.2\end{array}$ \\
\hline $\begin{array}{cc}\mathrm{CH}_{2} \mathrm{CHOHCHOHCH} \\
I_{\mathrm{S}^{-}}\end{array}$ & $k_{\mathrm{iH}}^{b}$ & $16.6 \pm 0.2^{a}$ \\
\hline
\end{tabular}
complex with doubly deprotonated dithiol.

${ }^{3}$ Lower case $k$ 's are used to represent microscopic (site specific) acid-dissociation and complex formation constants.
TABLE 2. Formation constants for methylmercury(1I)-dithiol complexes

${ }^{a}$ Determined by nmr; $25^{\circ} \mathrm{C}, 0.3 \mathrm{M} \mathrm{KNO}_{3}$. Uncertainties are the standard error of the estimate obtained from KINET fits.

${ }^{b}$ Microscopic constant as defined in Fig. 5 .

'Determined by potentiometric titration; $25^{\circ} \mathrm{C}, 0.1 \mathrm{M}_{\mathrm{KNO}}$. Uncertainties are one standard deviation obtained from MINIQUAD fits.

The constants $k_{3}$ and $K_{\mathrm{dp}}$ were determined by titrating an equimolar mixture of $\mathrm{CH}_{3} \mathrm{Hg}(\mathrm{II})$ and DMSA at high $\mathrm{pH}$ with acid, until incipient precipitation ( $\mathrm{pH} 4)$. A nonlinear least-squares fit of the titration data, using the rigorously weighted algorithm in KINET (10), to the algebraic model obtained from the equilibrium and mass balance equations, gave the values $\mathrm{p} k_{3}=$ $9.86 \pm 0.06$ and $K_{\mathrm{dp}}=0.6 \pm 0.2$ for DMSA. The titration data could not be fitted to a simple model involving only protonated and deprotonated 1:1 complex (eq. [3]) because the uncomplexed sulfhydryl group of the $1: 1$ complex still has a very high affinity for $\mathrm{CH}_{3} \mathrm{Hg}$ (II) so that, even at $1: 1 \mathrm{CH}_{3} \mathrm{Hg}$ (II): dithiol ratios, a significant amount of $2: 1$ complex is present.

Direct substitution of the $P_{\mathrm{f}}$ values obtained from the chemical shift titration data into eq. [2] and using these values for $k_{3}$ and $K_{\mathrm{dp}}$ yielded a value of $\log k_{\mathrm{fH}}=17.16 \pm 0.05$. The formation constants calculated for the deprotonated $1: 1$ complex and the 2:1 complex (eqs. [5] and [6]) ${ }^{2}$

[5] $\mathrm{CH}_{3} \mathrm{Hg}^{+}+{ }^{-\mathrm{S} \mathrm{S}^{-}} \rightleftarrows \mathrm{CH}_{3} \mathrm{HgS} \mathrm{S}$

$$
K_{\mathrm{f1}}=\frac{\left[\mathrm{CH}_{3} \mathrm{HgS \textrm {S } ^ { - }}\right]}{\left[\mathrm{CH}_{3} \mathrm{Hg}^{+}\right]\left[\overrightarrow{\mathrm{S} \mathrm{S}}^{-}\right]}
$$

[6] $\mathrm{CH}_{3} \mathrm{Hg}^{+}+\mathrm{CH}_{3} \mathrm{HgS} \mathrm{S} \mathrm{S}^{-} \rightleftarrows \mathrm{CH}_{3} \mathrm{HgS} \mathrm{S} \mathrm{HgCH}_{3}$

$$
K_{\mathrm{r} 2}=\frac{\left[\mathrm{CH}_{3} \mathrm{HgS} \mathrm{SHgCH}\right]}{\left[\mathrm{CH}_{3} \mathrm{Hg}^{+}\right]\left[\mathrm{CH}_{3} \mathrm{HgS} \mathrm{S}^{-}\right]}
$$

using these values are listed in Table 2 .

For DTE, precipitate formation in the presence of $\mathrm{CH}_{3} \mathrm{Hg}(\mathrm{II})$ precluded the measurement of a chemical shift titration 


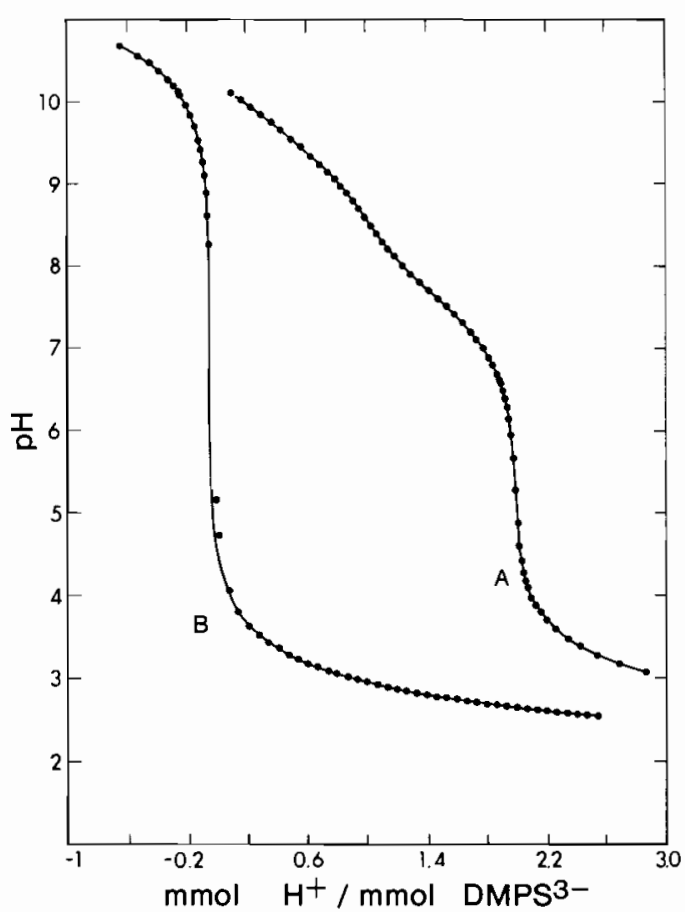

FIG. 2. Potentiometric titration curves for the $\mathrm{CH}_{3} \mathrm{Hg}$ (II)-DMPS system. $(A)$ with and $(B)$ without ME competition. The fitted curves are calculated using the constants in Tables 1 and 2 . (A) $1.186 \times 10^{-3}$ $M \mathrm{CH}_{3} \mathrm{Hg}(\mathrm{II}), 1.134 \times 10^{-3} M$ DMPS, $3.799 \times 10^{-3} M \mathrm{H}^{+}$(total titratable), $1.178 \times 10^{-3} M \mathrm{ME},(B) 2.563 \times 10^{-3} M \mathrm{CH}_{3} \mathrm{Hg}(\mathrm{II})$, $1.250 \times 10^{-3} M$ DMPS, $3.168 \times 10^{-3} M \mathrm{H}^{+}$(total titratable).

curve. However, replicate measurements on a 2:1:1 MAA: $\mathrm{CH}_{3} \mathrm{Hg}(\mathrm{II})$ : DTE solution at $\mathrm{pH} 12.2$ gave a value for $\log k_{\mathrm{fH}}$ of 16.6. The value used for $k_{3}$ in this calculation (Table 1) was calculated from $\mathrm{pH}$ data for the titration of an equimolar solution of DTE and $\mathrm{CH}_{3} \mathrm{Hg}$ (II) from high $\mathrm{pH}$ to $\mathrm{pH} 9$, using a value of 0.6 for $K_{\mathrm{dp}}$.

Curve $D$ in Fig. 1 is chemical shift titration data for MAA in a solution containing MAA, $\mathrm{CH}_{3} \mathrm{Hg}(\mathrm{II})$, and DMPS. The intermediate chemical shift again indicates displacement of MAA by the dithiol, but because DMPS is not symmetrical, it was not possible to derive an algebraic model such as that for DMSA. However, since the MAA shift lies closer to that of $\mathrm{CH}_{3} \mathrm{Hg}$ (II)-MAA, it can be concluded that the conditional formation constant, defined by eq. [7],

[7] $K_{\text {fC }}$

$$
=\frac{\left[\mathrm{CH}_{3} \mathrm{Hg}(\mathrm{II})\right. \text { complexed by dithiol] }}{\text { [uncomplexed } \left.\mathrm{CH}_{3} \mathrm{Hg}(\mathrm{II})\right][\text { uncomplexed dithiol } \mathrm{SH}]}
$$

is less, under these conditions, than that for the $\mathrm{CH}_{3} \mathrm{Hg}(\mathrm{II})-$ DMSA system.

\section{Potentiometric determination of formation constants}

Formation constants for the $\mathrm{CH}_{3} \mathrm{Hg}$ (II) complexes of DMPS and BAL were determined by potentiometric titration. It has been demonstrated previously (2) that protons cannot compete effectively with $\mathrm{CH}_{3} \mathrm{Hg}$ (II) in the presence of monothiols, necessitating the use of a competitive ligand such as iodide, in order to use the potentiometric titration method. In this work, 2-mercaptoethanol (ME) was used to compete with the dithiols for $\mathrm{CH}_{3} \mathrm{Hg}(\mathrm{II})$. The $\mathrm{CH}_{3} \mathrm{Hg}$ (II) complex of ME has been characterized previously $\left(\log \mathrm{K}_{\mathrm{f}}=16.13(2), 16.12(11)\right)$, and has no acid-base behavior, which keeps the number of species in the competition complexation model to a minimum. Repre-

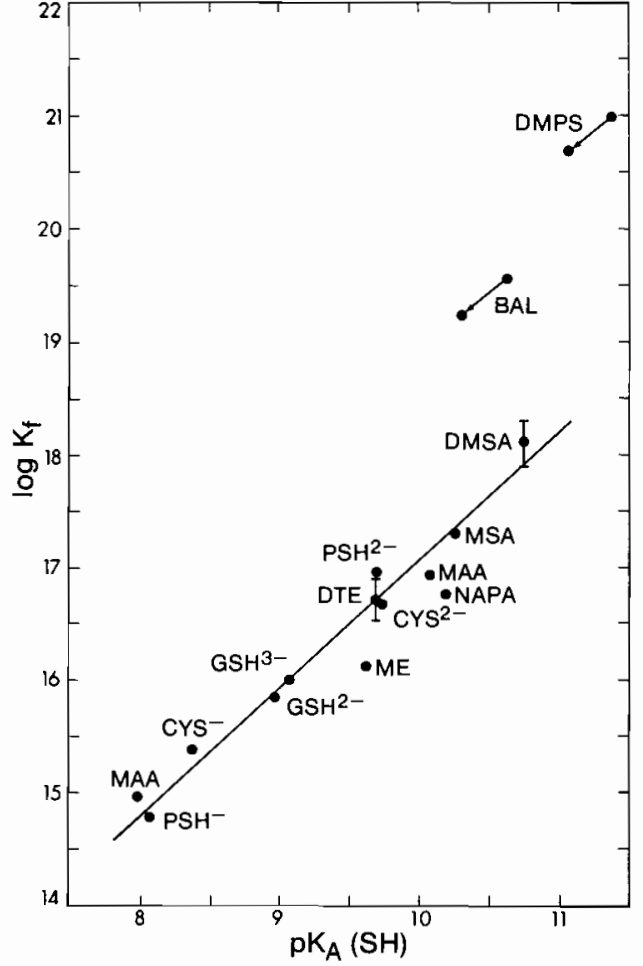

FIG. 3. Correlation between the microscopic $\log K_{\mathrm{f}}$ of $\mathrm{CH}_{3} \mathrm{Hg}(\mathrm{II})-$ thiol complexes and the microscopic $\mathrm{p} K_{\mathrm{A}}$ of the thiol groups. ME, MAA, BAL, DMPS, DMSA, and DTE are defined in the text. $O$-MAA is $O$-methylmercaptoacetate, $\mathrm{PSH}^{-}, \mathrm{CYS}^{-}$, and $\mathrm{GSH}^{2-}$ the amino-protonated, thiol-deprotonated and $\mathrm{PSH}^{2-}, \mathrm{CYS}^{2-}$, and $\mathrm{GSH}^{3-}$ the completely deprotonated forms of penicillamine, cysteine, and glutathione, respectively, NAPA is $\mathrm{N}$-acetylpenicillamine and MSA is mercaptosuccinic acid. Data for the monothiols are from [1], [2], and [4].

sentative titration data for the $\mathrm{CH}_{3} \mathrm{Hg}$ (II)-DMPS system are shown in Fig. 2. Equilibrium constants were obtained from titration data using a version of MINIQUAD (12) by procedures described previously (2).

Potentiometric titration curves for mixtures containing equimolar amounts of BAL or DMPS and $\mathrm{CH}_{3} \mathrm{Hg}(\mathrm{II})$ and ME could be fitted very well to a simple model involving only protonated and deprotonated 1:1 $\mathrm{CH}_{3} \mathrm{Hg}$ (II)-dithiol complexes along with the complex of ME. The values obtained for $K_{\mathrm{rH}}, \mathrm{K}_{3}$, and $K_{\mathrm{fl}}$, eqs. [1], [3], and [5], are listed in Tables 1 and 2.

The formation constants for the $2: 1$ complexes of BAL and DMPS, eq. [6], were obtained from titration data of 2:1 $\mathrm{CH}_{3} \mathrm{Hg}(\mathrm{II})$ : dithiol mixtures in the absence of ME. Under these conditions, the first sulfhydryl group is always complexed and, because of the lower affinity of the second sulfhydryl group for $\mathrm{CH}_{3} \mathrm{Hg}(\mathrm{II})$, the proton can compete effectively with $\mathrm{CH}_{3} \mathrm{Hg}$ (II) for this binding site. It is convenient to consider the $1: 1 \mathrm{com}-$ plex as a ligand in the presence of $\mathrm{CH}_{3} \mathrm{Hg}$ (II). The values obtained for $K_{\mathrm{f} 2}$ for the BAL and DMPS systems are listed in Table 2.

The equilibrium constants obtained potentiometrically for the $\mathrm{CH}_{3} \mathrm{Hg}(\mathrm{II})-\mathrm{DMPS}$ complexes have been used to predict the chemical shift titration curve for MAA in the mixture used in the nmr study of the $\mathrm{CH}_{3} \mathrm{Hg}$ (II)-DMPS system. The experimental and predicted curves are shown in Fig. 1, and the similarity between the two indicates good agreement between the $\mathrm{nmr}$ and potentiometric methods, considering the differences in experimental conditions. 


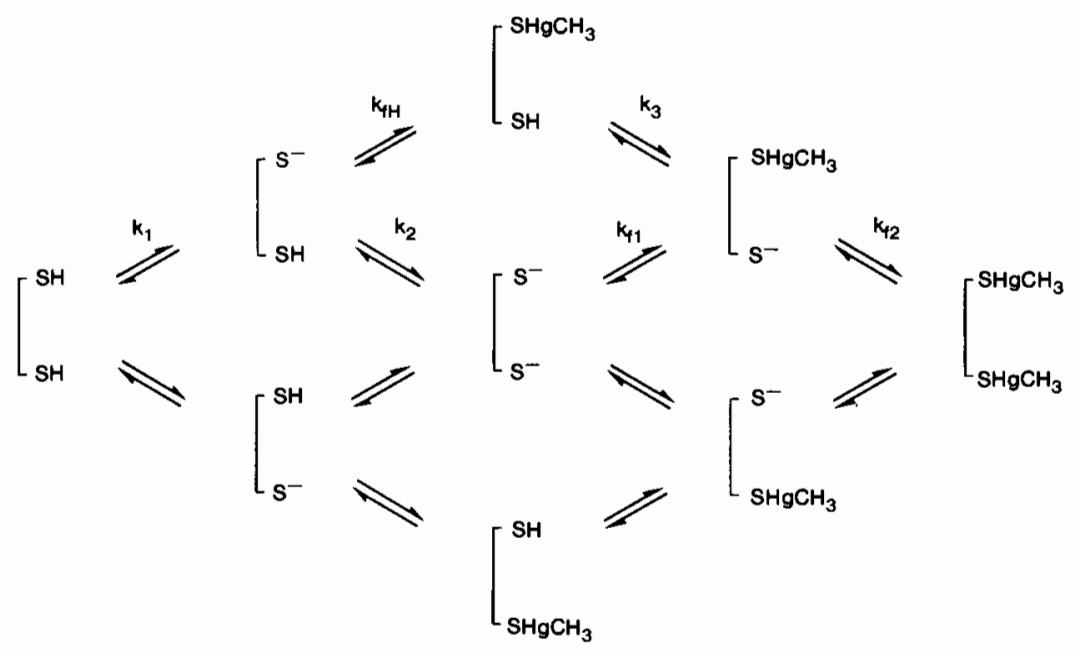

FIG. 4. Microscopic acid-base and complexation equilibria for the thiol groups of DMSA and DTE in solutions containing $\mathrm{CH}_{3} \mathrm{Hg}(\mathrm{II})$.

Attempts were made to determine formation constants for the $\mathrm{CH}_{3} \mathrm{Hg}$ (II)-DMSA complexes by potentiometry. However, even in equimolar $\mathrm{CH}_{3} \mathrm{Hg}(\mathrm{II})$ : dithiol solutions containing an excess of ME, significant amounts of $2: 1 \mathrm{CH}_{3} \mathrm{Hg}$ (II) : dithiol complex are present because of the high affinity of the second sulfhydryl of DMSA for $\mathrm{CH}_{3} \mathrm{Hg}$ (II). It was not possible to refine the equilibrium constants in this system with MINIQUAD because they are too highly correlated. However, titration curves calculated with equilibrium constants obtained from the nmr study gave a good fit to the experimental $\mathrm{pH}$ titration curves.

\section{Discussion}

The results in Tables 1 and 2 provide evidence for chelation in the sulfhydryl-deprotonated 1:1 $\mathrm{CH}_{3} \mathrm{Hg}$ (II) complexes of BAL and DMPS but not in those of DMSA and DTE. Chelation is indicated by the formation constants of the $1: 1$ deprotonated complexes, $K_{\mathrm{fl}}$, which are significantly higher for the DMPS and BAL complexes than for the DMSA and DTE complexes. Figure 3 shows the relationship between the microscopic formation constant, $k_{\mathrm{fl}}$, and the microscopic sulfhydryl acid dissociation constant for the $\mathrm{CH}_{3} \mathrm{Hg}$ (II) complexes of a series of monothiols $(1,2,4)$ and the symmetrical dithiols DMSA and DTE. The microscopic acid dissociation and formation constants for DMSA and DTE are defined in Fig. 4, and for DMSA are related to the macroscopic constants by $k_{1}=K_{3} / 2, k_{2}=$ $2 K_{4}, k_{\mathrm{f} 1}=K_{\mathrm{f} 1} / 2$, and $k_{\mathrm{f} 2}=2 K_{\mathrm{f} 2}$. While it was not possible to obtain the analogous microscopic constants for unsymmetrical BAL and DMPS, limits can be determined from the macroscopic constants and these are plotted in Fig. 3.

The monothiols and DMSA and DTE show the expected ( 1 , 13) linear correlation between $\log \mathrm{K}_{\mathrm{f}}$ of their $\mathrm{CH}_{3} \mathrm{Hg}$ (II) complex and the $\mathrm{p} K_{\mathrm{A}}$ of the coordinating group. However, it is apparent that the $\mathrm{CH}_{3} \mathrm{Hg}$ (II) complexes of BAL and DMPS are considerably more stable than would be expected by consideration of the basicity of the donor sulfur alone. We interpret this to be evidence for chelation of $\mathrm{CH}_{3} \mathrm{Hg}$ (II) in the deprotonated 1:1 complexes of BAL and DMPS. Chelation is also consistent with the lower sulfhydryl basicity in the deprotonated 1:1 complexes compared with once-protonated uncomplexed dithiol; for the protonated BAL and DMPS complexes $\mathrm{p} K_{3}$ is significantly less than $\mathrm{p} K_{1}$ for the doubly protonated dithiols whereas for the protonated DMSA and DTE complexes $\mathrm{p} K_{3}$ is slightly larger. Proton displacement followed

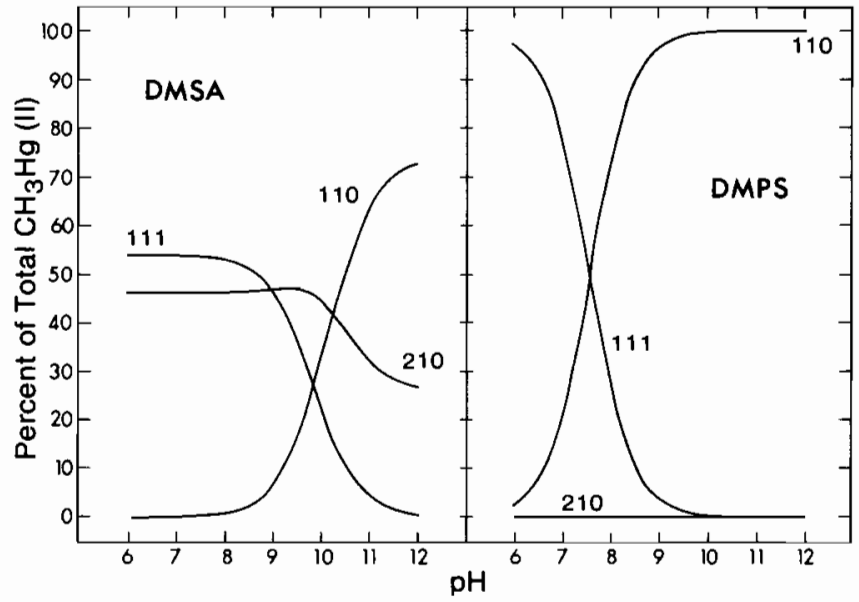

FIG. 5. Percent of total $\mathrm{CH}_{3} \mathrm{Hg}(\mathrm{II})$ in the various complexed forms, $\mathrm{M}_{m} \mathrm{~L}_{l} \mathrm{H}_{h}$ where $m, l$, and $h$ are given by three numbers by each curve, as a function of $\mathrm{pH}$ in solutions containing $0.001 \mathrm{M} \mathrm{CH}_{3} \mathrm{Hg}(\mathrm{II})$ and $0.001 M$ dithiol. Calculated using the constants in Tables 1 and 2.

by chelation lowers $\mathrm{p} K_{3}$ for the BAL and DMPS complexes. Alcock, Lampe, and Moore (9) have shown that $\mathrm{CH}_{3} \mathrm{Hg}(\mathrm{II})$ is chelated by sterically rigid vicinal dithiols in the solid state.

It seems reasonable to suggest that chelation is not present in the 1:1 complex of DMSA, despite the vicinal sulfhydryl groups, because of the resultant unfavorable proximity of the two deprotonated carboxylate groups which would result in this case.<smiles>O=CC1C=CC2CC(C=O)C1[S-]C2[S-]</smiles><smiles>O=C([O-])C1=CC=CC([S-])C1C(=O)[O-]</smiles><smiles>O=C([O-])C1CC([S-])C(C(=O)O)C1[S-]</smiles>

In this complex, the two sulfhydryl groups act more independently than is the case for the analogous complexes of BAL and DMPS. This is indicated by the stepwise formation constant, $\log K_{12}$, which for the addition of the second $\mathrm{CH}_{3} \mathrm{Hg}$ (II) cation to DMSA is $\mathrm{I} 6.9$ but is reduced to 10.46 and 10.26 in the BAL and DMPS complexes by chelation in the $1: 1$ complexes.

The large differences in the relative magnitudes of $K_{\mathrm{f} 1}, K_{\mathrm{f}}$, and $K_{\mathrm{rH}}$ for the DMSA, BAL, and DMPS complexes result in quite different distributions of $\mathrm{CH}_{3} \mathrm{Hg}$ (II) among the possible 
complexes, as illustrated by the species distribution diagrams in Fig. 5 for the DMSA and DMPS complexes. For the DMSA system, a large fraction of the $\mathrm{CH}_{3} \mathrm{Hg}(\mathrm{II})$ is present as the $2: 1$ complex whereas, for the DMPS system, the 2:1 complex represents $<0.1 \%$ for the conditions in Fig. 5 .

Since BAL, DMPS, and DMSA have all been used as antidotes for various forms of heavy-metal poisoning, it is appropriate to consider the nature of the $\mathrm{CH}_{3} \mathrm{Hg}(\mathrm{II})$-dithiol species expected to be present under physiological conditions. Using the equilibrium constants determined in this study, and a [dithiol]: $\left[\mathrm{CH}_{3} \mathrm{Hg}(\mathrm{II})\right]$ ratio of $20: 1$, the following complexed dithiol species are expected at $\mathrm{pH} 7.4$ :

DMPS

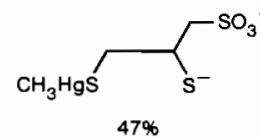

$47 \%$

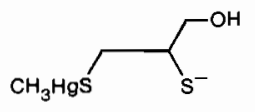

$39 \%$

DMSA
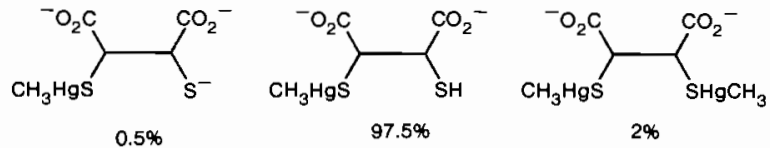

Mono- $\mathrm{CH}_{3} \mathrm{Hg}(\mathrm{II})$ species dominate for all the dithiols. For BAL and DMPS, about half of the complexed dithiol has a deprotonated sulfhydryl, while for DMSA, the analogous site is almost completely protonated. For DMSA and DMPS, all the major species are negatively charged. This is consistent with observed removal of $\mathrm{CH}_{3} \mathrm{Hg}$ (II) via the kidney by these dithiols $(6,7,14)$. It is also known that these dithiols do not cross the red blood cell membrane, but do rapidly mobilize intracellular $\mathrm{CH}_{3} \mathrm{Hg}$ (II) (15 and footnote 4). Both are effective antidotes for $\mathrm{CH}_{3} \mathrm{Hg}$ (II) poisoning $(6,7,15)$.

On the other hand, a large fraction of $\mathrm{CH}_{3} \mathrm{Hg}$ (II) complexed BAL is in the form of a neutral species under these conditions. Consistent with the expected lipophilic character of neutral BAL complexes, 1-octanol/water partition coefficients, $\left[\mathrm{CH}_{3}\right.$ $\mathrm{Hg}(\mathrm{II})]_{\text {octano }} /\left[\mathrm{CH}_{3} \mathrm{Hg}(\mathrm{II})\right]_{\text {water }}$ for [dithiol] : $\left[\mathrm{CH}_{3} \mathrm{Hg}\right.$ (II) $]$ ratios of $1: 1$ at $\mathrm{pH} 6.9$, are ca. $10^{4}$ greater for BAL than for DMSA and DMPS (16). Although this dithiol is an effective antidote for many other metals, including inorganic $\mathrm{Hg}$ (II), it redistributes $\mathrm{CH}_{3} \mathrm{Hg}$ (II) across the blood-brain barrier into the brain, and is contraindicated in cases of $\mathrm{CH}_{3} \mathrm{Hg}$ (II) toxicity.

The effectiveness of DMSA and DMPS as antidotes for $\mathrm{CH}_{3} \mathrm{Hg}$ (II) toxicity when administered orally with food, as judged by the removal of $\mathrm{CH}_{3} \mathrm{Hg}$ (II) from the brain and blood of mice, is DMSA > DMPS (14). Although factors other than formation constants are expected to be important in the effectiveness of antidotes, e.g. metabolism of antidotes and their $\mathrm{CH}_{3} \mathrm{Hg}$ (II) complexes, and the solubility properties of complexes discussed above, it is appropriate to consider possible effects of the constants determined in this study.

Since $\mathrm{CH}_{3} \mathrm{Hg}(\mathrm{II})-$ thiol binding is extremely labile $(3,13$, 17), it is likely that $\mathrm{CH}_{3} \mathrm{Hg}$ (II) in biological systems is distributed among the various intra- and extra-cellular and mem-

${ }^{4}$ A. P. Arnold, R. Guy, and D. L. Rabenstein. Unpublished result.

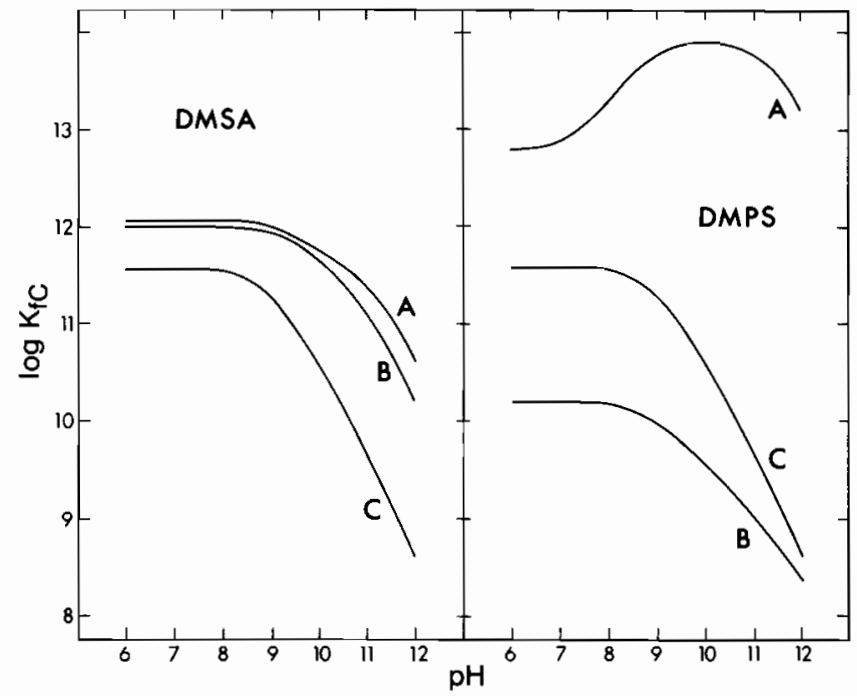

Fig. 6. $\mathrm{pH}$ and concentration dependence of the conditional formation constants for the $\mathrm{CH}_{3} \mathrm{Hg}(\mathrm{II})$-dithiol complexes and $\mathrm{pH}$ dependence of the conditional formation constant for the $\mathrm{CH}_{3} \mathrm{Hg}(\mathrm{II})-$ GSH complex (A) $0.001 M \mathrm{CH}_{3} \mathrm{Hg}$ (II), $0.01 M$ dithiol, $(B) 0.001 M$ $\mathrm{CH}_{3} \mathrm{Hg}(\mathrm{II}), 0.001 M$ dithiol. $(A)$ and $(B)$ were calculated with constants in Tables I and 2, the GSH curve $(C)$ was calculated with constants in [4]

brane bound sulfhydryl groups and those of antidote molecules according to an equilibrium model. If so, the relative effectiveness of DMSA and DMPS as antidotes may be related to the conditional formation constants, defined by eq. [7], of their $\mathrm{CH}_{3} \mathrm{Hg}$ (II) complexes and those of endogenous thiols at physiological $\mathrm{pH}$. The dependence of the conditional formation constants of the DMSA and DMPS complexes on dithiol: $\mathrm{CH}_{3} \mathrm{Hg}$ (II) ratio is shown in Fig. 6, together with $\log K_{\mathrm{fc}}$ for the $\mathrm{CH}_{3} \mathrm{Hg}$ (II) complexes of glutathione (GSH). Glutathione is the most abundant nonprotein thiol in biological systems (18), and has been identified as $\mathrm{CH}_{3} \mathrm{Hg}$ (II) binding site in red blood cells $(3,19)$ and liver cytosol $(20)$, and $30 \%$ of rat cerebral soluble $\mathrm{CH}_{3} \mathrm{Hg}$ (II) is in a GSH complex (21). The curves illustrate the complexity of the situation, since at high dithiol: $\mathrm{CH}_{3} \mathrm{Hg}(\mathrm{II})$ ratios such as those expected under antidotal conditions, log $K_{\mathrm{fc}}(\mathrm{DMPS})>\log K_{\mathrm{fc}}(\mathrm{DMSA})>\log K_{\mathrm{fc}}(\mathrm{GSH})$ but at low ratios the order is altered to $\log K_{\mathrm{fc}}(\mathrm{DMSA})>\log K_{\mathrm{fc}}(\mathrm{GSH})>\log$ $K_{\mathrm{rc}}$ (DMPS). At low dithiol: $\mathrm{CH}_{3} \mathrm{Hg}(\mathrm{II})$ ratios, ' $\mathrm{H}$ nmr studies of the removal of $\mathrm{CH}_{3} \mathrm{Hg}$ (II) from hemolyzed human erythrocytes (22) indicate that DMSA competes more effectively with intracellular thiols for $\mathrm{CH}_{3} \mathrm{Hg}$ (II) than DMPS.

\section{Acknowledgements}

This research was supported in part by the Natural Sciences and Engineering Research Council of Canada through its Strategic Grants Program and by the University of Alberta, and in part by the National Health and Medical Research Council (Australia).

A Commonwealth Postgraduate Research Award to A.P.S., and an I. W. Killam Fellowship to R.S.R. are gratefully acknowledged.

1. R. S. Reid and D. L. Rabenstein. Can. J. Chem. 59, 1505 (1981).

2. A. P. Arnold and A. J. Canty. Can. J. Chem. 61, 1428 (1983).

3. D. L. Rabenstein, A. A. IsAB, and R. S. Reid. Biochim. Biophys. Acta, 696, 53 (1982). 
4. R. S. Reid and D. L. Rabenstein. J. Am. Chem. Soc. 104, 6733 (1982).

5. J. AASETh. Acta Pharmacol. Toxicol. 39, 289 (1976).

6. L. Magos. Brit. J. Pharmacol. 56, 479 (1976).

7. B. Gabard. Acta Pharmacol. Toxicol. 39, 250 (1976).

8. M. BERLIN, L.-G. JeRKSELl, and G. NordBERG. Acta Pharmacol. Toxicol. 23, 312 (1965).

9. N. W. Alcock, P. A. Lampe, and P. Moore. J. Chem. Soc. Dalton Trans. 1471 (1980).

10. J. L. DYE and V. A. NicEly. J. Chem. Educ. 48, 443 (1971),

11. G. SCHWARzENBACH and M. Schellenberg. Helv. Chim. Acta, 48, 28 (1967).

12. A. Sebatini, A. Vacca, and P. Gans. Talanta, 21, 53 (1974); R. N. Sylva and M. R. Davidson. J. Chem. Soc. Dalton Trans. 465 (1979).

13. D. L. Rabenstein. Acc. Chem. Res. 11, 100 (1978).

14. J. AASETH and E. A. H. FrIEdHeIM. Acta Pharmacol. Toxicol. 42, 248 (1978).

15. J. Aaseth, J. Alexander, and J. Deverill. Chem.-Biol. Interactions, 36, 287 (1981).

16. A. P. Arnold, A. J. Canty, P. W. Moors, and G. B. Deacon. J. Inorg. Biochem. 19, 319 (1983).

17. D. L. Rabenstein and R. S. Reid. Inorg. Chem. 23, 1246 (1984).
18. P. C. JOCELYN. Biochemistry of the SH group. Academic Press, New York. 1972. p. 10.

19. A. Naganuma and N. Imura. Toxicol. Appl. Pharmacol. 47, 613 (1979).

20. S. Omata, K. Sakimura, T. Ishil, and H. Sugano. Biochem. Pharmacol. 27, 1700 (1978).

21. D. J. Thomas and J. C. SMith. Toxicol. Appl. Pharmacol. 47, 547 (1979).

22. D. L. Rabenstein, R. S. Reid, and A. A. Isab. J. Inorg. Biochem. 18, 241 (1983).

23. G. R. LENZ and A. E. MARTELl. Inorg. Chem. 4, 378 (1965).

24. I. E. OKONISHNikova, L. G. Egorva, V. L. NironberG, and I. Y. Postovskil. Khim.-Farm. Zh. 4, 21 (1970).

25. A. Agren and G. Schwarzenbach. Helv. Chim. Acta, 38, 1920 (1955).

26. D. L. Leussing and J. P. Mislan. J. Phys. Chem. 64, 1908 (1960).

27. P. J. Antikainen and K. Tevanen. Suomen Kemi. 35B, 224 (1962).

28. A. T. Pilipenko and O. P. RYABushKo. Ukrain. Khim. Zh. 32, 622 (1966).

29. P. J. Antikainen and V. M. K. Rosi. Suomen Kemi. 36B, T32 (1963). 